Meta

Journal des traducteurs

Translators' Journal

\title{
Publishing Strategies of Translated Children's Literature in Argentina
}

\section{A Combined Approach}

\section{Cecilia Alvstad}

Volume 48, numéro 1-2, mai 2003

Traduction pour les enfants

Translation for children

URI : https://id.erudit.org/iderudit/006973ar

DOI : https://doi.org/10.7202/006973ar

Aller au sommaire du numéro

\section{Éditeur(s)}

Les Presses de l'Université de Montréal

\section{ISSN}

0026-0452 (imprimé)

1492-1421 (numérique)

Découvrir la revue

\section{Citer cet article}

Alvstad, C. (2003). Publishing Strategies of Translated Children's Literature in Argentina: A Combined Approach. Meta, 48(1-2), 266-275.

https://doi.org/10.7202/006973ar

\section{Résumé de l'article}

Cet article présente les grandes lignes d'un projet de recherche ayant pour objet l'analyse des livres pour enfants publiés en Argentine en 1997, soit 56 ouvrages traduits et 94 non traduits. Dans ce projet, les livres traduits sont comparés aux livres non traduits d’un point de vue paratextuel, littéraire et linguistique. La traduction sera considérée en tant que procédé décisionnel. L’approche large proposée ici permet de comparer les décisions prises par les éditeurs et traducteurs dans différents domaines et surtout d'étudier les corrélations entre ces décisions. Les résultats de cette étude permettront d'approfondir notre connaissance de la traduction pour enfants et de la littérature destinée aux enfants publiée dans un contexte argentin. Par ailleurs, ils seront d'une grande importance, en particulier pour des questions d'ordre méthodologique telles que le choix du corpus. 


\title{
Publishing Strategies of Translated Children's Literature in Argentina. A Combined Approach
}

\author{
CECILIA ALVSTAD \\ Göteborg University, Göteborg, Sweden \\ cecilia.alvstad@rom.gu.se
}

\begin{abstract}
RÉSUMÉ
Cet article présente les grandes lignes d'un projet de recherche ayant pour objet l'analyse des livres pour enfants publiés en Argentine en 1997, soit 56 ouvrages traduits et 94 non traduits. Dans ce projet, les livres traduits sont comparés aux livres non traduits d'un point de vue paratextuel, littéraire et linguistique. La traduction sera considérée en tant que procédé décisionnel. L'approche large proposée ici permet de comparer les décisions prises par les éditeurs et traducteurs dans différents domaines et surtout d'étudier les corrélations entre ces décisions. Les résultats de cette étude permettront d'approfondir notre connaissance de la traduction pour enfants et de la littérature destinée aux enfants publiée dans un contexte argentin. Par ailleurs, ils seront d'une grande importance, en particulier pour des questions d'ordre méthodologique telles que le choix du corpus.
\end{abstract}

\section{ABSTRACT}

This article is a presentation of the general framework of a research project in which 56 translated and 94 non-translated books published for children in Argentina during 1997 are analyzed. In the project, the translated books are compared with the non-translated ones from paratextual, literary and linguistic viewpoints. Translation is considered to be a decision-making process and the broad approach proposed here makes possible a comparison of the decisions taken by publishers and translators in different areas and, most importantly, to the interrelations of these decisions. The results will increase the general knowledge of translation for children and of literature published for children in an Argentinean context. Moreover, they will be of importance for methodological issues such as the selection of corpora.

\section{MOTS-CLÉS/KEYWORDS}

publishing policy, paratext, children's literature, descriptive translation studies, Argentina

\section{Introduction}

The objective of this article is to present the framework of a current project researching into the translation of contemporary children's literature in Argentina. More precisely it will indicate the goal of the project, the corpus, a few central methodological issues and some preliminary results.

Argentina is of interest to Translation Studies because of its complex linguistic and cultural relationship to Spain and other Spanish-speaking countries. An example of this is that a great number of children's books (among them translations) are imported to Argentina from Spain, but not the other way around, in spite of the fact that there has been significant production of children's literature in Argentina in the 1980 's and 1990's. Another example of this complex relationship is that Argentinean 
Spanish in some respects differs linguistically from peninsular Spanish and other variants.

The project was initiated in order to acquire a better understanding of translated children's literature in this specific national context. The general goal of the project is to describe and discuss the Argentinean publishers' concept of translation as it is manifested in translated children's books. Important questions are: What children's books are being translated in Argentina? Why are precisely these books translated there? How are they translated?

The concept of translation might differ between publishers. Or as (Toury 1995: 58) expresses it "Different policies may of course apply to different subgroups [...] e.g., different publishing houses." The publishing house is therefore an important factor to take into account in the analysis. It is assumed here that the overall strategy of the publishing house, and especially its specialization towards either translated or non-translated literature, is of particular importance. Therefore the translations published by publishing houses specializing in non-translated books will be compared with translations published by publishing houses specializing in translations.

The nature of the subject area is very broad and branches into many areas of paratextual, ${ }^{1}$ literary and linguistic features in the books and could include studies of economic, ideological, sociological and cognitive data. However, the scope of this project has been limited to the following indicative areas: (1) paratextual features related to the publisher, (2) standard Spanish vs. Argentinean Spanish, (3) proper names, (4) literary themes and (5) syntactic structures.

Still, the general goal could not be achieved even in a profound analysis of all these features, if the results of the analysis of the translations were not compared with something. In this research project the translations are therefore compared with non-translations published in the same target culture at the same time, i.e., the project is in fact a synchronic analysis of children's books published in Argentina. Attention is paid to how translated literature for children relates to non-translated literature for children: What is published as non-translations as compared with what is published as translations? What are the similarities and differences between translated and non-translated books?

These are relevant questions as translated text often is assumed to be different from non-translated text within Translation Studies. Baker claims for example that: "Access to comparable corpora should allow us to capture patterns which are either restricted to translated text or which occur with a significantly higher or lower frequency in translated text than they do in originals" (Baker 1995: 235, cf. also her examples). Also in reference books on children's literature, translations are often treated in a different way than non-translations. This is the case with the book by Mehl (1992) in which more than 500 children's books published in Argentina are commented on. In the introduction Mehl states: "I propose a discussion on children's books circulating in our country, without the intention of making a selection or a repertoire or without classifying them in order of importance or excellence" (Mehl 1992: i, my translation). In spite of Mehl's explicit wish not to make a selection of the books "circulating" in the country, translations are, in fact, excluded without any comments, as if they did not exist.

The goal of the project implies a target-oriented approach. The study is thus conceived within Descriptive Translation Studies, especially as presented by Toury 
(1995). This project focuses on actual books published as translations, i.e., on the products. However, as Toury (1995: 11) points out, if one wants to explain the textuallinguistic make-up of a translation, it is not possible to ignore either the process by which it came into being, nor the function it has in the target culture.

Translation is assumed to be a decision-making process in this study. Every item in children's books - e.g., the cover, the name of the publisher, author and translator; different literary aspects such as themes, motifs and points of view; stylistic and linguistic features such as frequent words, syntactic complexity and the use of dialect is the result of decisions made by those involved in the translation process. Toury's (1995: 53-69) norm concept is central as a descriptive tool. Norms govern the behaviour of the decision-makers - translators, publishers and others involved in the translation process - and therefore the actual set-up of the translation. In this study it is therefore assumed that recurrent features in books published as translations provide the opportunity to indirectly study the regularities of behaviour of the decision-makers. The regularities of behaviour in their turn show evidence of possible norms constraining the translation process.

Children's literature is here defined as books published for children or young people. ${ }^{2}$ By book is understood anything with an ISBN-number and by for children what the publisher considers to be for children or young people. More precisely, for the purposes of the present study a book is considered a children's book if at least one of the following conditions is met: (1) if stated on or inside the book that it is for children, (2) if it is included in the publisher's catalogue of children's books, or (3) if it is mentioned as such in the general catalogue of the publisher.

Similar criteria are used to identify books as translations. If (1) a source language other than Spanish, (2) a translator, or (3) an agreement about the translation is mentioned in the paratext situated on or inside the book, this book will be considered to be a translation in this study. Otherwise the book is a non-translation. Thus, according to the distinction by Jakobson ([1959] 1989: 55), only interlinguistic translations (and not intralinguistic) are analyzed as translations in this project.

Publishing strategies are emphasized in the research project. The definition of children's literature given above implies that publishing houses decide whether to publish a book for children or for adults. Obviously, publishers decide whether to publish a book at all and therefore whether to publish translations and/or non-translations. But even if this seems to be an evident fact, very little attention has been paid to the role of the publishing house in the translation process (there are exceptions, e. g., Hemmungs Wirtén 1998).

If one takes into account that publishers select the books (translations and nontranslations) to be published, it becomes obvious that there is a need to emphasize the role played by the publisher in translation. Particularly, as publishers also select the translators and decide whether or not to translate the whole text, whether to keep the illustrations from the source text, whether to add illustrations to a text without illustrations, whether to give a style-sheet with linguistic or other recommendations to the translator, whether to change the translator's text and whether to publish the book in a series, and in that case, which one, etc. ${ }^{3}$ In other words, the publisher is crucial in the mediation between the source text and the source culture on the one hand and the target culture and the target culture reader on the other.

Toury (1995: 183) claims that it is not possible to tell from an analysis of books 
exactly who made which decisions. Therefore the 'translator' in many studies is a "hypothetical construct, i.e., a functional entity mediating between two existing texts, rather than a definite person." However, even though Toury is right and such a hypothetical construct is a useful methodological tool, it is problematic to label it 'translator' as the translator is one of several agents who constitute the hypothetical construct. It is especially problematic if one takes into account that another of the agents constituting the hypothetical construct, the publisher, is superior to the translator in many respects. As shown above, the publisher can intervene in the translator's decisions and change them, but not the other way around. Anyway, to simply replace the label 'translator' with 'publisher' is also unfortunate as the publisher also is one of the several agents constituting the hypothetical construct. We therefore prefer to name this hypothetical construct 'mediator' reserving the use of 'translator' and 'publisher' to the agents generally associated with these professions.

Assumingly, the publishers' strategies affect all the aspects that are studied in this project but to different degrees. They are most important in the creation of the paratext. They are also very important where themes are concerned as these presumably are closely related to the process in which books are selected for translation. It is also important to be aware of the ability publishers have to manipulate themes by adding or subtracting, with or without the translator's and/or the author's knowledge. There is, of course, also a possibility that translators modify the themes with or without the publisher noticing it. Domestic and foreign linguistic elements and syntactic complexity are domains where the translators clearly make decisions. Still, these features can be mentioned in guidelines to the translators and can easily be changed in the publishing house after the translator has handed in the manuscript.

\section{The Corpus: 150 Children's Books Published in Argentina in 1997}

In order to analyze the children's books published as translations and those published as non-translations, a corpus was compiled consisting of 150 books published in Argentina by ten different publishing houses in 1997. As the word corpus in the last decade has become almost synonymous with corpus held in an electronic form (as, for example, in the work of Baker, $c f$. her definition 1995: 226 or in Corpus Linguistics), it is important to stress that this corpus is not machine-readable and is therefore analyzed manually. The main reasons for not working with the corpus in a machinereadable form are: (1) most of the aspects to be dealt with in this project are not electronically searchable, (2) most of the publishers were reluctant to give the permissions to scan the books, a fact that would have influenced the choice of the books to be integrated in the corpus, and (3) it is time-consuming to scan children's books because of the many decorations and illustrations. The corpus is monolingual (in Spanish) and includes both translations and texts that are not translations. Except for not being machine-readable it is therefore a comparable corpus following the terminology proposed by Baker (1995: 234).

The corpus is thus limited to children's books published in one year (1997). Even though choosing one year was arbitrary, it provided a principle for the establishment of the corpus. It made it possible to integrate books from many different publishers and therefore to compare the books published as translations with those published 
by these publishers as non-translated books in the target culture. But, if another year had been chosen the amounts of books published and the percentage of them being translations would most probably have been different. The Argentinean political and economic situation has changed radically during the last decades (dictatorship to democracy, hyperinflation to no inflation to deep crisis). This certainly affects the publishing of books, and in particular the purchase of foreign copyrights in foreign currencies. Anyway, it is assumed here that the publishers' concept of translation does not change as fast as the political and economic situation. It is also assumed that one year provides a good ground for predictive hypotheses for other years and other places, hypotheses that later can constitute a base for further studies on the subject.

The reason for choosing 1997 was purely practical: the corpus was established in October-November 1998 when books published in 1997 could still be obtained. In Argentina some children's books remain on the market for many years and are reprinted when they are out of stock. Others, especially low prestige books, e.g., most co-productions, only circulate on the market for a short time. Low prestige literature is also almost impossible to find in libraries. Three main sources were used to find the books: ISBN-statistics provided by Cámara Argentina del Libro (1998), the publishers' catalogues and 41 informal interviews with publishers, authors, translators, etc. carried out in $1998 .^{4}$

In this way a total of about 175 children's books published in Argentina in 1997 were found. With some 25 exceptions (non-narrative and books by small or bankrupt publishers) all the books published in 1997 were integrated into the corpus. The non-narrative books were not included as there were no translations in this category. The books by small publishers were excluded for the same reason and also because it was difficult to locate some of them. Bankrupt publishers were excluded because it was impossible to find out exactly which books they published in 1997 and to get hold of these. Of the 150 books in the corpus 56 are translations and 94 are nontranslations, according to the criteria given above.

\section{Preliminary Results}

In accordance with the general goal of the research project, preliminary analyses on the basis of the corpus have been made with the aim of describing and comparing the editorial paratext, the proper names and standard Spanish vs. Argentinean Spanish (Alvstad 2001; 2002; forthcoming a; forthcoming b). The analyses aimed, on the one hand, at studying differences between the translated books and the target culture non-translations, and, on the other hand, at studying differences between translations published by different publishers. The results presented here come predominantly from the paratextual study.

Eight paratextual features were taken into consideration in Alvstad (2001). Three of them can by definition only appear in translations: the mention of the source language, whether the book is claimed to be a co-production, and the name of the translator. The other five parameters can figure in both translations and non-translations: the name of the author, whether the book is part of a series, the recommended age of the reader, the number of pages, and the presence/absence of illustrations. The main results of the paratextual study are the following: 


\section{Source Language Identified:}

41 of the 56 translations in the corpus were translated from English. The others were translated from French, German, Italian or Portuguese. No translations were introduced from African, Asian, Australian, East European or Nordic source cultures (Alvstad 2001: 61).

\section{Co-Productions:}

Co-productions are books printed in several languages at the same time. In interviews with Argentinean editors and translators it became clear that sometimes there is a written source text, which is translated but it is also common that the 'translated' text is created on the basis of the illustrations only. 26 of the 56 translations in the corpus are co-productions (Alvstad 2001: 62).

\section{Translator Identified:}

The name of the translator is clearly indicated together with the word 'translator' or 'translation' in 34 of the 56 translations. In the other 22 translations the name of the translator is indicated but in a disguised way. Author-like formulations such as 'texts by...' or 'texts:...' are common ways of referring to the translator in the paratext. Eight books were published by translators who also have been published as authors of Argentinean books (Alvstad 2001: 64-67).

\section{Author Identified:}

The name of the author is only indicated in 34 of the 56 translations (61\%) whereas it is always indicated in the non-translations (Alvstad 2001: 75).

\section{Published as part of a Series:}

All translations except three are published in a series. Most of the non-translations are also published in series but not in the same ones as the translations. Most of the translations, 45 exactly, are included in series that only include translations. Eight translations are integrated in series that also include non-translations (Alvstad 2001: 81). This is an important difference between translations and non-translations.

\section{Recommended Reader Age Identified:}

The marketing of children's books in Argentina is very oriented towards specific reader-ages. The recommended age of the reader is often printed on the cover of the book. 26 of the translations are directed towards the ages of $0-4$ years old and 26 to the ages 8-11. This means that there are hardly any (only four) translations for other ages (5-7 and 12-16 years). This is a major difference from the non-translations because non-translations are published for many different reader ages. The amount of books published for readers 0-4, 5-7, 8-11 and 12-16 years old are 21, 24, 28 and 21 respectively (Alvstad 2001: 89-90).

\section{Page Length of Publication:}

The length of the translations is stereotype. 26 of the translations are shorter than 17 pages and 23 are between 97-128 pages. Only seven translations have other lengths. This is also an important difference as compared with the non-translations. Lengths of the non-translations are much more varied: there are eight non-translations up to 16 pages, 35 between 17 and 32, 16 between 33 and 64, 16 between 65 and 96, 8 between 97 and 128, and 11 longer than 128 pages (Alvstad 2001: 92-93). 


\section{Presence/Absence of Illustrations:}

38 of the 56 translations $(68 \%)$ and 82 of 94 non-translations $(87 \%)$ are illustrated (Alvstad 2001:94-95). Illustrations in black and white are more frequent in nontranslations than in translations. $37 \%$ of the illustrations in the non-translations are in black and white, which can be compared with $23 \%$ of the illustrations in the translations. The results of the paratextual study thus show important differences as far as the five analyzed features that can appear in both translations and non-translations are concerned.

A closer look at the 56 translations show that they, on the basis of the eight paratextual features studied, can be divided into three different categories:

1) The 26 co-productions all of which are directed towards readers up to four years old. They are shorter then 16 pages and are illustrated in colour. They are translated by translators who have not been published as authors (in that name). The translators are often mentioned with author-like formulations whereas the names of the authors of the source book are generally not mentioned. Source languages are English, French and Italian.

2) 21 translations, which are directed towards readers between 8 and 11 years old. They are between 97 and 128 pages long and translated by translators who have not been published as authors (in that name). Both authors and translators are mentioned in the books. All these books are translated from English. It is also clear from the paratext that all these books are to be classified as suspense.

3) The 'odd ones.' There are nine translations that do not fall into any of the two stereotype categories above. Their lengths are different (two are between 16 and 32, three are between 32 and 64, two are between 96 and 128, and two are longer than 129 pages). They are directed towards different age groups (three towards 5-7, five towards 8-11, and one towards 12-16 years old). Eight of the nine books are translated by authors of other books. Moreover, eight of the books (not identical with the eight mentioned above) are published in series together with non-translations. Furthermore, eight of the nine books are illustrated (four of them in black and white and four in colour). In three of these books the illustrations are created for the translations and in one they are considerably changed as compared with the source book. Source languages are English, German and Portuguese.

All of the books in the first two categories were published by publishers specializing in translations. Eight of the nine books in the third category were published by publishers specializing in non-translations. The translations in the third category are more like the non-translations, as far as the paratextual features studied are concerned, than like the other translations.

The preliminary results concerning the proper names in the corpus show that there are important similarities between translated and non-translated books (Alvstad forthcoming a). In most books for children up to the age of seven (21 translations and 28 non-translations) only domestic names are used. In most books for children between 8 and 16 years old ( 24 translations and 27 non-translations) domestic and foreign names are combined. But there are also some important differences. There are considerably more books without proper names among the non-translations than among the translations ( $14 \%$ as compared with $2 \%)$. The names used in the non-translations are 'stranger' and more creative like the domestic names Filotricina, Nemesia, Circenia, Ruslán and the foreign names Moc, Poc and Ahl. In the translations 
both domestic and foreign proper names are more standardized (Juana, Kenny). The nine translations mentioned above as the 'odd ones' differ from the other translations. Two of them use exclusively domestic proper names for children between 8 and 11 years old. The others differ in the way domestic and foreign names are combined, in one book there are for example multiple geographical and historical references to Argentinean places or persons.

The analysis of standard Spanish vs. Argentinean Spanish deals with two different ways of expressing the second person singular 'you' (Alvstad forthcoming b). In standard Spanish 'you' (second person singular) is expressed with the pronoun tú, whereas in Argentina vos is the general way of expressing the same meaning. According to the bibliography on the subject this is even so in formal styles (Fontanella de Weinberg 1992: 150) and in literary texts (Carricaburo 1999, all the examples in this study are taken from non-translated literature for adults). In spite of what could be assumed from these studies, the preliminary analysis shows that vos is hardly used at all to express second person singular in the translations. Only three of them use the Argentinean vos and in all these three translations vos is combined with tú. This indicates that translated children's books follow other norms concerning the use of standard Spanish and Argentinean Spanish than the non-translated books for adults analyzed in Carricaburo (1999). The three translations with vos are all translated by authors, that is, they are three of the nine 'odd' translations. Further analysis is needed of the 94 non-translations in the corpus to see if non-translated Argentinean children's literature also differs from the norms for non-translated adult literature or if $t u$ is a feature typical of translations.

The main question in the literary analysis is whether the themes that appear in the translations and the non-translated books are similar or different. Is there, for example, a thematic contribution by the translations to the target culture? How stereotypic are the themes? Are there any differences in this respect between the books published by different publishers? One of the working hypotheses is that themes are more stereotypic in the translations by publishers specializing in translations than in the other translations and in the target culture non-translations.

The fact that syntactic complexity varies considerably depending on the age of the intended reader is taken into account in the syntactic case study. A mini-corpus with excerpts from the books for one age group (8-11 years) is used to study aspects like word order and punctuation. The working hypothesis is that the non-translations and the translations published by the publishers specializing in non-translations, manifest a more complex syntax, with more instances of subordination, coordination, colons and semicolons than the translations by publishers specializing in translations.

\section{Final Words}

The objective of this article has been to present the theoretical and practical framework of a research project in progress that will provide more knowledge and a better understanding of translating for children in Argentina, and especially of the Argentinean publishers' concept of translation. The project is a broad study that provides the possibility to compare norms pertaining to paratextual, literary and linguistic areas. Attention is also paid to if and how decisions taken in different areas interrelate. 
The project calls into question the tendency to analyze translations and nontranslations of the target culture as two distinct units. There seem to be different kinds of translations in the corpus and some of them are quite different as compared to non-translated literature. Other translations are more similar to non-translated books than to the overall category of translations. This would imply that it is problematic to treat translated and non-translated literature as two isolated and different categories.

Moreover, attention is paid to the role of the publisher, an area that so far has been largely neglected in current research on translation, in spite of the fact that the publisher is one of the most important mediators between the source text and the recipient of the translation.

Furthermore it shows that manual analyses of carefully selected corpora are important and necessary. Paratextual features cannot be studied without direct access to the books. To study literary themes, reading the books is unavoidable. It is not easy to find domestic and non-domestic elements electronically, simply because it is not possible to know what to search for. It could be any proper name, food, label, etc. To do research on word order is possible in a carefully tagged corpus but it would require much more work to scan and tag the corpus than to do a manual analysis, etc. ${ }^{5}$

Last but not least, the project adds to the study of translated children's literature and translated literature generally. And, even though it is not part of the general goal, this project also provides general knowledge of non-translated children's literature in Argentina, since the translations are compared with books that are not translations. This is important since little research has been carried out so far on children's literature in Argentina.

\section{NOTES}

1. Paratext is what presents the literary text and makes it a book, e.g., title, name of the author, preface, illustrations ( $c f$. Genette 1982: 9, 1987: 7).

2. Townsend (1971: 10) has suggested that the decisive criteria for a book to be categorized as a children's book is that it is listed as such by the publisher. Cf. Hunt (1991: 42-64) for a discussion of Townsend's and other definitions of children's literature.

3. Even in those cases when somebody (a translator) who is not a publisher decides to translate a book and then presents it to a publisher, it is the publisher who makes the decision whether to publish the book, whether to publish it in the translation by that translator and whether to introduce changes into the translation.

4. For more information about the publisher's catalogues and the interviews $c f$. Alvstad (2001: 51-52, 112-114).

5. See van Doorslaer (1995) and Rolhe-Neves (2000) for further discussions on selection and representativeness of corpora in Translation Studies.

\section{REFERENCES}

Alvstad, C. (2001): Normas paratextuales en traducciones. Un modelo descriptivo de libros para niños y jóvenes orientado a la cultura meta. Göteborgs Universitet, Institutionen för romanska språk.

- (2002): ¿Señor Cooney eller Sr. Moscoso? Om användningen av inhemska och utländska egennamn i översatta barn- och ungdomsböcker. En M. Koskela \& N. Pilke (ed), 48-57. LSP and Theory of translation. 22nd Vakki Symposium. Vaasa 9- 10.2.2002. Vaasa: Vaasan yliopisto, 2002. 
— (Forthcoming a) "Lengua estándar en literatura infantil traducida en Argentina." Primer Congreso Internacional "Traducción y literatura para niños," Las Palmas de Gran Canaria, Spain, 20-23 March 2002. Conference Papers.

- (Forthcoming b) "Proper Names in Children's Literature Published in Argentina." Paper presented at "Translation (Studies): A Crossroads of Disciplines," Faculty of Letters, University of Lisbon 14-15 November 2002.

Baker, M. (1995): "Corpora in Translation Studies: an Overview and Some Suggestions for Future Research." Target 7:2.

Cámara Argentina del Libro (1998): Libros argentinos (CD-Rom). Isbn: 950-9394-17-3.

CARricaburo, N. (1999): El voseo en la literatura argentina. Madrid: Arco Libros.

van Doorslaer, L. (1995): "Quantitative and Qualitative Aspects of Corpus Selection in Translation Studies." Target 7:2.

Fontanella de Weinberg, M. B. (1992): El español de América. Madrid: Mapfre.

Genette, G. (1987): Palimpsestes. Paris: Éditions du Seuil

- (1982) Seuils. Paris: Éditions du Seuil.

Hemmungs Wirtén, E. (1998): Global infatuation. Explorations in Transnational Publishing and Texts: the Case of Harlequin Enterprises and Sweden. Uppsala: Avd. för litteratursociologi vid Litteraturvetenskapliga institutionen.

Hunt, P. (1991): Criticism, Theory, and Children's Literature. Oxford: Blackwell.

Jakobson, R. ([1959] 1989): “On Linguistic Aspects of Translation.” In: Readings in Translation Theory, A. Chesterman (ed), 53-69. Helsinki: Oy Finn Lectura.

MenL, R. (1992): Con este sí, con este no: más de 500 fichas de literatura infantil argentina. Buenos Aires: Ediciones Colihue.

Rolme-Neves, R (2000): "On Justification in Translation Studies: Some Comments and a Research Report.” Target 12:1.

Toury, G. (1995): Descriptive Translation Studies - and beyond. Amsterdam \& Philadelphia: John Benjamins.

Townsend, J. R. (1971): A Sense of Story: Essays on Contemporary Writers for Children. London: Longman. 